\title{
Critical Success Factors in Post ERP Implementation
}

\section{H.S.C. Perera and T. Withanage}

Abstract: Enterprise Resource Planning (ERP) systems are popular as IT enabled tools which integrate differentfunctional areas of businesses. ERP systems are implemented as total business solutions, which support major functionalities of businesses. Many studies have addressed on critical success factors (CSF) in ERP implementation, but with attention has been given for CSFs in post ERP implementation. This research is designed to identify the CSFs in post ERP implementation. Factors influencing on post ERP implementation planning and post implementation stages were identified through literature surveys and opinions of the industry experts. The Degree of influence of these factors for post implementation planning and correlation between the identified factors and ERP successes as were determined through a questionnaire distributed among the ERP user companies.

Keywords: ERP Systems, PostERP Implementation, Critical Success Factors

\section{Introduction}

Today the business environment is becoming more and more complex with different functional areas requiring more inter-functional communication through sharing of enterprise data across the organization. In this context, Enterprise Resource Planning (ERP) systems have become the obvious choice in managing organizational data and business practices. An ERP system is a software system for business management encompassing modules supporting functional areas such as planning, manufacturing, marketing, distribution, accounting, finance, human resource management, inventory management, service \& maintenance, transportation, and e-business [1].

ERP systems as a whole may well count as the most important tool in the corporate use of information technology in the 1990s [2]. Not only in 1990s even today it is one of the most important IT enabled management tool which attempts to integrate all the business functions in to a one single system giving full control over large and medium size businesses. Because of its tangible and intangible benefits, most of the large and mid size organizations have implemented or are in the process of implementing ERP systems expecting higher KOI (Return on Investment) and better control over their businesses. Since early 1990s, ERP systems have become the de facto standard for the replacement of legacy systems in large and multinational companies [3].

ERP implementations are usually large complex projects involving large groups of people and other resources working together under considerable time pressure and facing many unforeseen developments. It brings a considerable amount of changes into organizational practices and yield dramatic improvements in business practices giving huge returns on investment. Not surprisingly many of these implementations turn out to be less successful than what was originally intended $[2$, $4,5]$. Not only that, according to Griffith [6] 75\% of ERP projects are classified as failures. This implies that ERP implementation has a lot of Critical Success Factors (CSFs) and undoubtedly they will become cornerstones of any ERP implementation. During last few decades many studies have been carried out on CSFs in ERP implementation [e.g. 3, 7]. But these studies have mainly focused on the implementation stage of the project or the selection phase.

Even though information systems have been conceptualized in the past studies [e.g. 8] as the process that leads to a decision about choice, design and development there are not much studies on the issues related to post implementation planning which plays a vital role in the successful implementation of a business system. This study attempts to identify the critical success factors in post ERP implementation and to provide recommendations for successful post ERP implementation.

Eng. (Dr.) H.S.C. Perera, B.Sc.Eng. (Moratuwa),M.Eng. (AIT),D.Eng. (AIT), MIE(Sri Lankn), Senior Lecture'r, Department of Manage'ment of Technology, University of Morntuwa.

Eng. T. Withanage, B.Sc. Eng. (Morntuwn), AMIE (Sri Lamkn), Head of Application (Mamufacturing IFS Research and Development (Pot)Ltd. 


\section{Literature Review}

\subsection{What is ERP?}

An ERP system, which is used to manage enterprise data, has become a vital tool in business decision making. ERP systems help organizations to deal with supply chain, receiving, inventory management, customer order management, production planning, shipping, accounting, human resource management and other business functions [9]. So an ERP system can be identified as a large software package which comprises of many smaller segments but which shares common data and business practices throughout the entire organization. Also it helps to access online information created by business transactions. The ERP system is the main information infrastructure of an organization. It will serve as the backbone for any other information system and integration among these systems facilitating the data flow among them.

Rosemann [10] has defined an ERP system as a customizable software package, which manages data from various organizational activities and provides which fully integrated solutions to major organizational data management problems. It provides information for both the core administrative functions, such as human resource management and accounting as well as integrated modules which can be selected to support key business processes such as warehousing, production and client management

\subsection{Phases in ERP Projects}

An ERP implementation project takes time, ranging from 6 months to 3 years depending on the size and the scope of the project. Therefore clearly defined phases can be seen in an ERP implementation project. This is past research work on how an implementation process of an enterprise system should be broken down into different phases. The Implementation of an ERP system implies that a company must focus on, evaluate and define relevant company processes in precise details [11]. According to Parr and Shanks [11] ERP implementation begins with planning. After planning is completed the project team will move through a number of discrete project phases. After the ERP system is up and running, there may be postimplementation review and later a stabilization phase.

Different researchers have identified ERP implementation phases differently. Ross and Vitale [12] have defined ERP implementation phases as Design, Implementation, Stabilizing, Continuous Improvement and Transformation. Bancroft et al. [13] identifies five phases for ERP implementation as, focus, as-is, to be, construction and testing and actual implementation. Markus and Tanis [14] have used the process theory approach to identify stages in ERP implementation. According to them, ERP implementation has following four main phases:

i. Chartering - Decisions defining of the business case solution

ii. Project - Getting system and end users up and running

iii. Shakedown - Stabilizing, eliminating "Bugs", getting to normal operations

iv. Onward and upward -Maintaining systems, supporting users, getting results, upgrading and systems extensions

Out of the above the four phases shakedown and onward \& upward phases can be considered as the postERP implementation stage.

\subsection{ERP Success}

A large number of research can be found on ERP successes as and failures [e.g. 2, 15, 16, 17]. While some of them have considered ERP successes others have done their research on failures. According to Molla and Loukis [18], one of the reasons behind these different views lies in the multidimensionality of the concept of success and the difficulty of developing a single success or failure measurement. On the other hand inability to meet expectations can be considered as failures and some times companies have incurred negative returns on investments as a result of such failures.

Measuring the success of an implementation project involves a number of variables but they can be categorized under three main categories. A successful acquisition of ERP systems can be achieved in several ways. The DeLone and 
McLean [17] model is an important contribution on Information System (IS) success measurement. This model measures project success in following six dimensions: system quality, information quality, information use, user satisfaction, individual impact and organizational impact. Same can be used in measuring the success of an ERP system. Hong and Kim [19] have proposed a different model. They have defined success as achievement of Home predetermined goals, which include multiple parameters such as time, cost, and functions. But according to a study done by Baccarini [20], project success can be attributed to two main categories as 'Project Management Success' and 'Project Product Success'. By being over lime and/or budget, project can be deemed a project management failure but the resulting product can be a success. Therefore overall suc cess of a project can be defined as the totality of the project management success and project product success (i.e. Project Success $=$ Project Management Success + Project Product Success)

In the literature, success factors of ERP implementation have been widely addressed. However issues related to post ERP implementation have been addressed by few researchers only. The post implementation stage of ERP involves a lot of activities and is the period where you see the result of work done during the project phase. Following the implementation of a system, an organization would engage in a number of activities such as post-implementation review, support and maintenance [21]. Also during this period, users are tired by working for a long period of time without seeing a result. Therefore this period is a very stressful period which is crucial in achieving initial goals and objectives. The following are some of the factors that need attention during this phase: training, post ERP depression, forecasting future hardware/ software needs, budgeting, identification of priorities and standards. Wider and Davis [22] recognize that lack of user training and failure lo completely understand how enterprise application changes business processes are important factor of failure.

\section{Research Methodology}

\subsection{Research Design}

The number of factors to be considered in ERP implementation across the entire life cycle is large. Critical Success Factors (CSFs) in the post implementation stage become a subset of the CSFs in ERP implementation. CSFs in ERP implementation have been researched at various levels. But out of those, factors need to be considered in post ERP implementation planning play a vital role in aligning of the enterprise system with the company's business practices. To achieve ERP success all these CSFs should be achieved. Though some organizations have realized the importance of post implementation planning, some tend to neglect such planning due to the influence of external and internal factors. This study first finds the factors which influence post ERP implementation planning and their degree of influence. Then the study determines the correlation between the activities in the postERP implementation stage and ERP successes. These factors are initially identified through literature review and opinions of industry experts.

The overall success of ERP implementation is measured under two categories: project success and product success. Three indicators are used to measure project success: project completion within budget, project completion within the scheduled time and the completion of the project scope. DeLone and McLean [17] model is used to measure the ERP product success. This model measures the product success in following six dimensions;

i. System Quality - Quality of the system

ii. Information Quality - Quality of the information output

iii. Information Use - Recipients consumption of the information output

iv. User Satisfaction - Satisfaction level of the system users

v. Individual impact - Effect on the information recipient

vi. Organizational impact - Effect of the information on the organization

\subsection{Method of Data Collection}

The data collection is an integral part of research design. Quality and accuracy of the collected data will determine the quality and accuracy of the research. Therefore special consideration was given in designing the questionnaire and 
deciding on the data collection method. Since there were no adequate research studies on post ERP implementation, primary data were collected at the source level.

Out of the data collection methods available such as interviews, questionnaires, and observations, the questionnaire was selected as the data collection method. By considering the ease of data collection, reach and IT literacy among the people in the research domain, emails have been used as the medium of data collection. This method helped to reduce the cost and save time in data collection. Questions which reveal user or company identities were not included to ensure anonymity and thereby increase the response rate. Close ended questions were included in the questionnaire to make it effortless for the respondents in answering.

Around 50 questionnaires were distributed for collecting data and the number of respondents was 32. Members of top management and middle management were among the target group. The selected organizations had implemented ERP and have started their live run at least in one functional area.

\section{Analysis}

\subsection{Factors Influencing on Post ERP Implementation Planning}

In some of the ERP implementations, the organizations have not given enough consideration to the post implementation planning. Factors which influence the post implementation planning are discussed in this section. According to the responses received, validity of the identified factors is summarized in Table 1. The influence of these factors is measured on a five point Likert scale.
Table 1 - Factors Influenced on Post ERP Implementation Planning

\begin{tabular}{|l|c|c|}
\hline \multicolumn{1}{|c|}{ Factor } & Mean & $\begin{array}{c}\text { Std. } \\
\text { Deviation }\end{array}$ \\
\hline Cultural Influence & 4.28 & 0.729 \\
\hline $\begin{array}{l}\text { Work Load of Day- } \\
\text { to-day Activities }\end{array}$ & 4.19 & 0.859 \\
\hline Management Influence & 4.03 & 0.861 \\
\hline $\begin{array}{l}\text { Unawareness of Post } \\
\text { ERP Implementation } \\
\text { Planning }\end{array}$ & 3.56 & 0.840 \\
\hline $\begin{array}{l}\text { Monetary Constraints } \\
\text { Involvement of } \\
\text { vendor in Post }\end{array}$ & 3.53 & 0.671 \\
$\begin{array}{l}\text { Implementation } \\
\text { Planning }\end{array}$ & 2.91 & 0.818 \\
\hline
\end{tabular}

More than 90 percent of the respondents have agreed that cultural influence has affected their post ERP implementation while only 3.1 percent has disagreed. So a very high mean value of 4.28 out of 5 points has shown that this is the main reason for ignoring the post ERP implementation planning in most of the places. The workload of the day-to-day activities has become the second most important reason for not performing post ERP implementation planning with a mean of 4.19 on the 5 point scale. Only 6.3 percent of respondents have disagreed with this while 84.6 percent have agreed. As in any other phases of implementation, Management influence is also among the factors which affect post ERP implementation planning scoring a mean of 4.08. 78.3 percent have agreed with this while disagreeing percentage being low as 6.3 percent. Unawareness about Post ERP implementation planning, monetary constraints and vendor's involvement in planning have scored more than three points on the five point scale but comparatively lower average values than the first three factors. No one has strongly agreed that vendor should do the post implementation planning for them with a disagreeing percentage of 37.5 . 


\subsection{Factors Influenced on Post ERP Implementation Stage}

After studying the different activities carried out in Post ERP Implementation stage, level to which those activities were carried out was measured using a 5 point Likert scale. Table 2 depicts the individual mean values and standard deviations of the level in carrying out post ERP implementation activities in the selected organizations.

Table 2 - Post ERP Implementation Activities

\begin{tabular}{|l|c|c|}
\hline \multicolumn{1}{|c|}{ Activity } & Mean & Std. Deviation \\
\hline $\begin{array}{l}\text { IIser Training after } \\
\text { Go-Live }\end{array}$ & 4.29 & 0.437 \\
\hline Hug Fixing & 4.06 & 0.564 \\
\hline Job Roles Changed & 4.03 & 0.740 \\
\hline $\begin{array}{l}\text { Management Invol- } \\
\text { vement after Go-Live }\end{array}$ & 3.95 & 0.733 \\
\hline Job Enhancement & 3.94 & 0.716 \\
\hline $\begin{array}{l}\text { Change Management } \\
\text { Changes in Hardware }\end{array}$ & 3.91 & 0.777 \\
\hline $\begin{array}{l}\text { Business Processes } \\
\text { Changed }\end{array}$ & 3.69 & 0.767 \\
\hline $\begin{array}{l}\text { Identification of } \\
\text { Priorities }\end{array}$ & 3.66 & 0.602 \\
\hline $\begin{array}{l}\text { ('hanges to the Budget } \\
\text { Changes in Software }\end{array}$ & 3.34 & 0.701 \\
\hline
\end{tabular}

\subsection{ERP Success}

The degree of success of each ERP project was measured in order to identify the influence of factors in Table 2 on ERP project success. ERP success is measured using two main components;

i. ERP Project Success and

ii. ERP Product Success.

ERP project success is measured as follows:

ERP Project Success $=($ Within Budget + Within Time + Covered Scope) $/ 3$
Most of the projects have completed within the initial budget with a mean of 4 an the 5 point scale and covered the initial scope with a mean of 4.38 on the 5 point scale. But project completion against planed time has fallen little below with a mean value of 3.5 on the 5 point scale. Because of that overall project success has dropped to a mean value of 3.96 on the same scale but widely spread out between 1.67 and 5 points. Table 3 shows statistics of project success.

Table 3 - Components of Project Success

\begin{tabular}{|l|c|c|c|c|}
\hline & $\begin{array}{c}\text { Within } \\
\text { Budget }\end{array}$ & $\begin{array}{c}\text { Within } \\
\text { Time }\end{array}$ & $\begin{array}{c}\text { Scope } \\
\text { Comp } \\
\text { leted }\end{array}$ & $\begin{array}{l}\text { Project } \\
\text { Success }\end{array}$ \\
\hline $\begin{array}{l}\text { Sample } \\
\text { Size (N) }\end{array}$ & 32 & 32 & 32 & 32 \\
\hline Mean & 4.00 & 3.50 & 4.38 & 3.96 \\
\hline Median & 4.00 & 4.00 & 4.50 & 4.33 \\
\hline Mode & 4 & 4 & 5 & 4.67 \\
\hline $\begin{array}{l}\text { Std. } \\
\text { Deviation }\end{array}$ & 0.916 & 1.244 & 0.751 & 0.841 \\
\hline Minimum & 2 & 1 & 2 & 1.67 \\
\hline Maximum & 5 & 5 & 5 & 5.00 \\
\hline
\end{tabular}

Table 4 - Product Success and its Parameters

\begin{tabular}{|l|c|c|}
\hline \multicolumn{1}{|c|}{ Indicator } & Mean & $\begin{array}{c}\text { Std. } \\
\text { Deviation }\end{array}$ \\
\hline Accuracy of the System & 4.44 & 0.504 \\
\hline Timeliness of Information & 4.44 & 0.669 \\
\hline Stability of the System & 4.44 & 0.504 \\
\hline Clarity of the System & 4.25 & 0.508 \\
\hline $\begin{array}{l}\text { System Uses Correct } \\
\text { Method }\end{array}$ & 4.25 & 0.718 \\
\hline User Satisfaction & 4.16 & 0.677 \\
\hline $\begin{array}{l}\text { User-friendliness of the } \\
\text { System }\end{array}$ & 3.72 & 0.729 \\
\hline $\begin{array}{l}\text { Response Time of the } \\
\text { System is Rapid }\end{array}$ & 3.69 & 0.592 \\
\hline Flexibility of the System & 3.47 & 0.842 \\
\hline Product Success & 4.09 & 0.474 \\
\hline
\end{tabular}


Product success is measured using 9 parameters including 4 parameters which measure the user satisfaction. Out of those 9 parameters, accuracy of the system, timeliness of information and stability of the system have scored the highest mean of 4.44 out of 5 and the user-friendliness, response time and flexibility of the system have scored lower mean valid. Overall Product Success has a mean of 4.09 on the 5 point scale and this is higher than the project Success which is 3.95 on the same scale. Therefore overall Success of the ERP product has a mean value of 4.09 percent with a Standard Deviation of 0.474 on the 5 point scale.

\subsection{Relationship between factors in ERP Post Implementation and ERPSuccess}

In analysing data, strong correlation can be found between product success and project success; Pearson correlation value of 0.798 has been observed between these two variables in the sample data set.
Then the relationship between those values and the ERP Successes as revealed strong relationship for Management Involvement, Business Process Changes and Job Role Changes among others. Bug Fixing and Hardware Changes also have a significant relationship to the Project Success. Correlation between post ERP implementation activities and ERP success is shown in Table 5.

\section{Conclusions}

ERP implementation differs from other information system implementations due to its integrative nature and complexity. ERP implementation projects take times ranging from one to five years depending on their size and the scope, Therefore ERP implementation projects can be broken into a set of clearly identifiable phases, as shown in the previous studies [e.g. 11, 12, 14]. So each of these phases can have different critical success factors, due to the unique nature of the work carried out in each phase.

Table 5 - Correlation between Post ERP Implementation Activities and Success

\begin{tabular}{|c|c|c|c|c|}
\hline \multicolumn{2}{|c|}{ Post Implementation Activities } & \multirow{2}{*}{$\begin{array}{c}\text { ERP } \\
\text { Success }\end{array}$} & \multirow{2}{*}{$\begin{array}{l}\begin{array}{l}\text { Product } \\
\text { Success }\end{array} \\
0.583^{* x}\end{array}$} & \multirow{2}{*}{$\begin{array}{r}\begin{array}{l}\text { Project } \\
\text { Success }\end{array} \\
0.660^{\prime \prime}\end{array}$} \\
\hline Business Processes Changed & Pearson Correlation & & & \\
\hline & Sig. (2-tailed) & 0.000 & 0.000 & 0.000 \\
\hline \multirow[t]{2}{*}{ Job Enhancement } & Pearson Correlation & $0.520^{\prime \prime}$ & $0.462 "$ & $0.513 "$ \\
\hline & Sig. (2-tailed) & 0.002 & 0.008 & 0.003 \\
\hline \multirow[t]{2}{*}{ Management Involvement after Go-Live } & Pearson Correlation & $0.486 "$ & $0.456 "$ & $0.467 "$ \\
\hline & Sig. (2-tailed) & 0.005 & 0.009 & 0.007 \\
\hline \multirow[t]{2}{*}{ Job Roles Changed } & Pearson Correlation & $0.389 *$ & 0.318 & $0.399 "$ \\
\hline & Sig. (2-tailed) & 0.028 & 0.076 & 0.024 \\
\hline \multirow[t]{2}{*}{ Bug Fixing } & Pearson Correlation & 0.259 & 0.312 & 0.209 \\
\hline & Sig. (2-tailed) & 0.153 & 0.082 & 0.250 \\
\hline \multirow[t]{2}{*}{ Changes in Hardware } & Pearson Correlation & 0.225 & 0.259 & 0.190 \\
\hline & Sig. (2-tailed) & 0.215 & 0.153 & 0.299 \\
\hline \multirow[t]{2}{*}{ User Training after Go-Live } & Pearson Correlation & 0.157 & 0.199 & 0.122 \\
\hline & Sig. (2-tailed) & 0.390 & 0.276 & 0.505 \\
\hline \multirow[t]{2}{*}{ Changes in Software } & Pearson Correlation & 0.144 & 0.097 & 0.160 \\
\hline & Sig. (2-tailed) & 0.431 & 0.597 & 0.382 \\
\hline \multirow[t]{2}{*}{ Change Management } & Pearson Correlation & 0.112 & 0.161 & 0.076 \\
\hline & Sig. (2-tailed) & 0.542 & 0.379 & 0.679 \\
\hline \multirow[t]{2}{*}{ Identification of Priorities } & Pearson Correlation & 0.067 & 0.041 & 0.077 \\
\hline & Sig. (2-tailed) & 0.714 & 0.823 & 0.675 \\
\hline
\end{tabular}

${ }^{* *}$ Correlation is significant at the 0.01 level (2-tailed) and ${ }^{*}$ Correlation is significant at the 0.05 level (2-tailed) 
Among the factors that influence the post implementation stage, changes made to the business processes have the highest contribution ID the ERP success. Thus the top management should give their attention to re-engineer the existing business process to obtain the maximum benefit of ERP implementation. Planned processes should be put into practice at this stage and practicalities of those processes are challenged by the actual users with a system go-live. So this is a crucial period which requires close monitoring of those processes. The second best relation to the ERP success was found in job enhancements made at the same stage. It is also noted that changes injob roles have a significant impact on ERP success. With the introduction of the new system certain job roles may become obsolete and some have to be enhanced as they $\mathrm{t}$ an have access to more important information required in their day-to-day work. This can help to increase the user happiness by showing the importance of their work to the organization. Similar to any other phase in ERP implementation, it was found that the Top Management's Involvement in the project after the go-live has contributed a lot to the project. In general involvement of managers at the Implementation is higher than that of the post implementation stage and the managers tend to relax a bit once the system starts the live run. But the managers involvement in the post Implementation is very important for the ERP surcess. In addition to the human factors mentioned above it is important to attend to ter hnical issues such as bug fixing and necessary hardware and software changes. Another important activity to be carried out at this stage is lo identify the gaps between end users ability and the skills required to operate the system. This will help to organize more training programs before users feel that the new system I* cumbersome to use.

Culture has affected post implementation planning. Then work load of the day-to-day rtdivilies has influenced a lot the post implementation planning and it could be due to the fact that users see it as an extra item of work lo their normal work. Management's influence, unawareness and monetary constraints are also r onsidered as the influencing factors for the post IUPimplementationplanning.
As clearly identified in this research there are some critical success factors (CSFs) related to post ERP implementation and post implementation planning. Senior Managers, Project Managers and Consultants should consider these factors as important.

\section{References}

1. Hossain L., Patrick, J. and Rashid, R., The Evolution of ERP Systems: A Historical Perspective, in Enterprise Resource Planning: Opportunities and Challenges, M.A. Idea Group Publishing, pp 160-187, 2002.

2. Davenport, T., Putting the Enterprise into the Enterprise System, Harvard Business Review, 76 (4), pp 121 - 131, 1998.

3. Holland, C., Gibson N., Christopher P., and Light B., Enterprise Resource Planning: A Business Approach to Systems Development, Proceedings of Hawaii International Conference on System Sciences, 1999.

4. Avnet, ERP Not Living up to Promise. Global Supply Chain 2 (1), 1999.

5. Buckhout, S.E, Frey, J. and Nemec, J.R., Making ERP Succeed; Turning Fear into Promise, Strategy and Business, Second Quarter 15, pp 60-72, 1999.

6. Griffith, T.L., Zummato, R.F. and Ayman, L., Why new technologies fail? Industrial Management, pp 29-34, 1999.

7. Willcocks L.P. and Sykes, R., The Role of the $\mathrm{CIO}$ and IT Function in ERP, Communications ofthe ACM, 43 (4), pp 32-40, 2000.

8. Nicolaou, A.I., Social Control in Information Systems Development, Information Technology \& People, 12 (2) pp. 130-150, 1999.

9. Somers, Nelson, T.M. and Ragowsky, K., Enterprise Resource Planning (ERP) for the Next Millennium: Development of an Integrative Framework and Implication of Research, Proceedings of the 6th Americas Conference on Information Systems (AMCIS), Long Beach, pp 998-1004, 10-13 August, 2003 , 
10. Rosemann M., ERP Software: Characteristics and Consequences, $7^{\text {th }}$ European Conference on Information Systems, Copenhagen, Denmark, 23-25 June 1999.

11. Parr, A.N. and Shanks, G., A Taxonomy of ERP Implementation Approaches, Proceedings of the $33^{\text {rd }}$ Hawai International Conference on System Sciences- Volume 7, p 7018, 2000.

12. Ross, J.W, and Vitale M.R., The ERP Revolution: Surviving versus Thrilling, Information System Frontiers, 2 (2), pp. 233241, 1998.

13. Bancroft N.H., Seip, H \& Sprengel, A., Implementing SAP R/3: How to Introduce a Large System into a Large Organization. Manning Publications Co., Greenwich, CT, USA, 1998.

14. Markus, M.L. and Tannis C., The Enterprise System Experience: From Adoption to Success, in Framing the Domains of IT Research: Glimpsing the Future Through the Past, R.W. Zmud (ed.), Cincinnati, OH: Pinnaflex Educational Resources, Inc., 2000.

15. Al-Mashari, M., Al-Mudimigh, A. and Zairi, M., Enterprise Resource Planning: A Taxonomy of Critical Factors, European Journal of Operational Research. 146, pp 352$364,2003$.

16. Bingi, P., Sharma, M. and Godla, J., Critical Issues Affecting an ERP Implementation, Information Systems Management. 16 (3), pp 714, 1999.

17. DeLone, W.H and McLean, E., Information System Success: The Quest for the Dependant Variable, Information System, 3, pp 60-95, 1992.

18. Molla, A. and Loukis, I., Success and Failure of ERP Technology Transfer: A Framework for Analysing Congruence of Host and System Cultures, Development Informatics Working Paper No. 24, IDPM, The University of Manchester, ISBN: 1904143679, 2005.

19. Hong, K.K. and Kim, Y.G., The Critical Success Factors for ERP Implementation: An organizational Fit Perspective, Information and Management, 40 (1), pp 25-40, 2002.
20. Baccarini, D., The Logical Framework Method for Defining Project Success, Project Management Journal, 30 (4), pp 25-32, 1999.

21. Gelinas, U. and Sutton, S., Accounting Information Systems, 5th edition. Boston, MA: South Western, 2002.

22. Wilder, C. and Davis, B., False Starts, Strong Finishes, Information Week, pp 41-53, Nov. 30, 1998. 